\title{
Wyobraźnia eschatologiczna. Dialog z antyczną tradycją w I księdze poematu Crisias Hilariona z Werony
}

\author{
Eschatological Imagination: Dialogue with the Ancient Tradition \\ in Book One of the Poem Crisias by Hilarion of Verona
}

\author{
KATARZYNA JANUS \\ Uniwersytet Humanistyczno-Przyrodniczy im. Jana Długosza w Częstochowie \\ katarzynajanusx@wp.pl, ORCID: 0000-0003-4897-3621
}

\begin{abstract}
Streszczenie: W artykule podjęto próbę filologicznej analizy i interpretacji I księgi eposu Crisias Hilariona z Werony. Wskazano liczne antyczne źródła zarówno z mitologii, jak i historii, które zostały wykorzystane przez pisarza w tworzeniu eschatologicznego imaginarium. Postawiono tezę o zamierzonym przez Hilariona z Werony intertekstualnym charakterze eposu jako swojego rodzaju wyzwaniu dla odbiorcy kardynała Bessariona. Hilarion z Werony jest mało znanym pisarzem włoskiego quattrocenta, dlatego też $w$ artykule przybliżono środowisko intelektualne, w którym tworzył autor Krysiady. Epos jest zupełnie nieznany w Polsce, prezentowany artykuł może stanowić prolegomena do jego lektury.
\end{abstract}

Słowa kluczowe: eschatologia, Crisias, Hilarion z Verony, mitologia, tradycja antyczna

Abstract: In this article an attempt is made to analyze and interpret the first book of the epos Crisias, by Hilarion of Verona. The purpose of the article is to identify and illuminate the ancient literary, historical and mythological sources used by that author to fashion an eschatological imagination. According to the thesis presented in this article, contextual references in Crisias constituted a path of communication between the writer, Hilarion of Verona, and the reader, Bessarion. Hilarion of Verona is an otherwise unknown writer of the Italian quattrocento, therefore a presentation of the intellectual environment within which that author operated is a necessary part of our analysis. The reflection offered in this paper can be treated as a prolegomena to further research, since the epos Crisias has never before been the focus of research within Polish scholarship.

Keywords: Eschatology, Crisias, Hilarion of Verona, mythology, ancient tradition

Celem artykułu jest prezentacja I księgi poematu Crisias Hilariona z Verony. Ten nieznany utwór zapomnianego autora włoskiego quattrocenta, z uwagi na liczne intertekstualne odniesienia w warstwie inwencji, jak również metryczne uporządkowanie i nasycenie środkami obrazowania poetyckiego, stanowi interesujący przedmiot badań. Przeprowadzone w niniejszym studium analizy mogą stanowić prolegomena do lektury kolejnych ksiąg eposu, którego kulturowe i teologiczne konteksty wymagają eksplikacji. 


\section{Autorstwo poematu i źródła legendy o znakach poprzedzających koniec świata}

W pierwszym wydaniu eposu pojawia się nota o problemach ze wskazaniem autora i czasu napisania poematu: „quos Verecundi esse Arevalus conjiciebat, alii vero fortasse vix saeculi XV esse concedent, alii longe vetustiores" ${ }^{1}$. Domniemane autorstwo Werekunda z Junki zostało zakwestionowane już kilka lat po publikacji poematu. W 1894 roku niemiecki patrolog Otto Bertram Bardenhewer², prezentując twórczość Werekunda, wzmiankuje o błędnej atrybucji sugerowanej przez wydawcę Krysiady, twierdząc, że jest to utwór o wiele późniejszy. Autorstwo ustalił Giovanni Pesenti w opublikowanym na łamach czasopisma Athenaeum artykule „Lautore e la data del poema Crisias"3. Lektura manuskryptu kodeksu watykańskiego ${ }^{4}$, gdzie oprócz samego tekstu poematu znajduje się napisane greką, złożony z 95 heksametrów enkomion kardynała Bessariona, pozwoliła także na ustalenie terminus ante quem, wyznaczonego datą śmierci adresata - 18 listopada 1472 roku. Ów dedykacyjny poemat zawiera

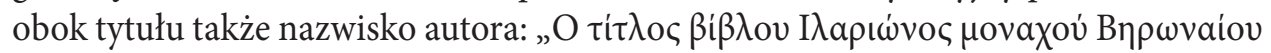

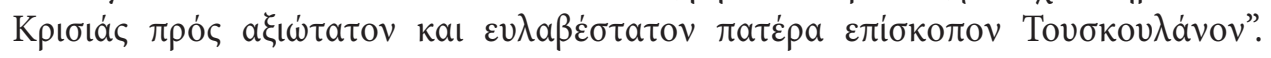
W opinii Giovanniego Pesentiego już same źródła inwencyjne, którymi w mniejszym zakresie są księgi sybillińskie, a w znacznym pogańskie wyobrażenia mitologiczne, są wystarczające, by nie wskazywać jako twórcy dzieła autora starożytnego. Zważywszy żywą obecność w literaturze średniowiecza legendy o piętnastu znakach mających poprzedzić Sąd Ostateczny, można było, jak twierdzi w dalszej części wywodu autor, śmiało postawić hipotezę o średniowiecznej proweniencji tekstu. Warto jednak w tym miejscu zaznaczyć, że ta legenda ma swoje źródła w pierwszych wiekach chrześcijaństwa. Najwcześniejszy zapis znaków znajdujemy w apokryficznej Czwartej Księdze Ezdrasza, która powstała za panowania cesarza Domicjana. W piątym i szóstym rozdziale księgi odnajdujemy, choć w innej kolejności, te znaki, które później są wymieniane przez pisarzy średniowiecza w anonimowych hymnach. Bez trudu można znaleźć inwencyjne źródła biblijne, dzięki którym tekst Czwartej Księgi Ezdrasza zasługuje na miano apokryfu. Znajdziemy tu liczne refleksy ksiąg prorockich Starego Testamentu: Izajasza (54,4), Ezechiela $(32,7 ; 38,20)$, Daniela (12,2-3), a także z ewangelii (Mt 24; Mk 13), listów (2 P 3-12; 1 Kor 15,52; Tes 4,16) i Apokalipsy św. Jana (6,15-16; 20,12-13). Wśród autorskich tekstów dawnych, w których legenda o piętnastu znakach ma swoje miejsce, należy wymienić XXVI rozdział VII księgi dzieła Divinae institutiones Laktancjusza, De civitate Dei

1 Korzystałam z edycji Crisias w Pitra, Spicilegium solesmense I, 144-150. W tekście podaję lokalizację cytatów w nawiasach okrągłych. Fragmenty po polsku we własnym tłumaczeniu.

2 Bardenhewer, Patrologie, 596.

3 Pesenti, „Lautore e la data del poema «Crisias»”, 123.

4 Codex Vaticanus Urbinas Latinus 737.

5 Starowieyski, Barwny świat apokryfów, 8. 
św. Augustyna ${ }^{6}$. Są też inne, takie jak tzw. Ewangelia Hebrajczyków, której przekładu na łacinę miał dokonać św. Hieronim. O obecności proroctwa w tym zaginionym apokryfie informuje anonimowy twórca jednego $\mathrm{z}$ hymnów ${ }^{7}$, przywołując postać autora Wulgaty jako tego, który miał dowiedzieć się o znakach ze wspomnianej Ewangeliii ${ }^{8}$. Piętnaście znaków poprzedzających Sąd Ostateczny znajdujemy również w pierwszej opowieści Złotej legendy Jakuba de Voragine - De adventu9. Popularność motywu znajduje też odzwierciedlenie w literaturze polskiej. Proroctwo znajdujemy na kartach wydanego w 1522 roku polskiego apokryfu ${ }^{10}$ Baltazara Opeca Żywot Pana Jezusa Chrystusa [...], a półtora wieku później w astronomicznym prognostyku Stanisława Słowakowica ${ }^{11}$. Wagę owych katastroficznych prognoz w średniowieczu potwierdzają też plastyczne wizualizacje. Opisane w literaturze znaki poprzedzające Sąd Ostateczny są tematem ilustracji w rękopiśmiennym utworze powstałym około połowy XV wieku Livre de la Vigne nostre Seigneur. Drzeworyty, wykonane przez cenionego paryskiego miniaturzystę, kaligrafa i ilustratora Antoine’a Vérarda, prezentujące te same wydarzenia, zdobią inkunabuł wydany 12 lutego 1453 roku w Paryżu, w oficynie André Bocarda - ars moriendi - L'art de bien vivre et de bien mourir. Te same motywy miały znaleźć się na wykonanym z początkiem XV wieku kilimie, należącym do książąt Burgundii. Informuje o tym Emile Mâle w studium poświęconym francuskiej religijnej sztuce późnego średniowiecza ${ }^{12}$.

Te wszystkie przykłady dowodzą popularności i znaczenia wizji, które pojawiły się jako literackie obrazy w apokryfach powstałych w pierwszych wiekach chrześcijaństwa i przez kolejne epoki działały na wyobraźnię artystów. Autor Krysiady - Hilarion z Werony (1440 - po 1485) opisał 15 znaków w trzeciej księdze. Informuje on, że zna proroctwa $z$ lektury tekstów źródłowych: Pisze: „At sunt, qui referant ter quinque horrenda praeire/ Signa haec iudicium, totum memorata per orbem" (III, 75) W opisie Hilariona ważną funkcję pełnią wprowadzone imiona postaci mitologicznych, np. Neptun - w poemacie metonimia morza - podniesie się według przepowiedni na 40 łokci powyżej masywu Acroceraunii. Inny reprezentatywny przykład zawiera werset określający położenie ludzi w czasie klęski głodu: lud pozbawiony jedzenia i picia charakteryzują słowa „non gustans munera Cereris et Bacchi” (II, 101). Mitologiczne

6 W XVIII księdze znajdujemy fragmenty wyroczni Sybilli ze słynnymi wersami stanowiącymi akrostych, układający się w napis Jezus Chrystus Boga Syn Zbawca. Ich treścią są znaki poprzedzające przyjście Chrystusa. Augustinus, De civitate Dei XVIII, 23, 255 sq.

7 Mowa o wydanym w 1505 roku w oficynie Martina von Werdena w Kolonii hymnie Signa quindecim horribilia de fine mundi et extremo iudicio.

8 Na temat apokryficznej Ewangelii Hebrajczyków zob: Starowieyski, Apokryfy Nowego Testamentu, 99-110: Romaniuk, „Apokryfy”, 762.

9 W edycjach z 1488 roku (oficyna Doneta Locatellego) i 1493 roku (Manfreda Bonellego) to św. Augustyn został wskazany jako autor owych 15 znaków, które miał odnaleźć w Ewangelii Hebrajczyków.

10 Zob. Opec, Żywot Pana Jezusa, 456-457.

11 Słowakowic, Postliminium cometarum, nlb. Proroctwa są przypomniane w II części rozprawy.

12 Mâle, L'art religieux, 480. 
wtręty stanowią twórczy wkład w legendę, podobnie jak umieszczone w tekście nazwy własne funkcjonujące w astrologii i w geografii. Te ostatnie są zarówno wyrazem erudycji autora, jak i próbą unaocznienia i uprawdopodobnienia katastrof. Wydaje się natomiast, że wprowadzenie elementów mitologicznych ma jeszcze inne znaczenie: intertekstualny system aluzji, cytacji, nawiązań zapewnia komunikację pomiędzy autorem i adresatem tekstu.

O autorze wiadomo niewiele. Milczą o nim kompendia biobibliograficzne. Dziś, jeśli postać pisarza i jego dzieło stają się przedmiotem zainteresowań badaczy, to Hilarion jest definiowany jako „minor” włoskiego quattrocenta ${ }^{13}$. Wiadomości o autorze istnieją dzięki hierarchom, którym, jak w przypadku Krysiady, dedykował swoje utwory, albo na których zamówienie pracował. Drugą obok kardynała Bessariona ważną osobą w kontekście dokonań literackich Hilariona z Werony był Francesco Todeschini Piccolomini, późniejszy papież Pius III, który z uwagi na swoje historyczne zainteresowania, zlecił mnichowi rewizję rzeczową i stylistyczną korektę biografii Einharda Vita Caroli Magni. Podstawowym źródłem była dla Hilariona Vita z IX wieku, ale wykorzystał też współczesną mu wersję biografii, spisaną przez florenckiego humanistę Donato Acciaiuoli. Powstało dzieło nowe, głównie poprzez nadanie mu przez autora antycznego kolorytu, czego dowodziło wprowadzenie licznych cytacji dzieł starożytnych twórców ${ }^{14}$. Krysiada jest najpewniej wcześniejszym dziełem niż biografia Karola Wielkiego ${ }^{15}$. Łączy te dwa dzieła wykorzystanie antycznych źródeł, co jest dowodem intelektualnej formacji i erudycji zarówno autora, jak i protektorów. Zarówno bowiem Tedeschini Piccolomini, jak i Bessarion byli ludźmi wykształconymi w zakresie języków i kultury klasycznej. Edukacją pierwszego z nich kierował wuj Eneas Silvio Piccolomini, poprzednik na Stolicy Piotrowej - mówca i pisarz znany z antycznych fascynacji. Postać, z uwagi na „warmiński” epizod - nominację wbrew woli króla polskiego na biskupa warmińskiego, jest przywoływana w historii Polski. Szukając rodzimych wątków odnośnie do Bessariona, odnotowujemy wydanie dwukrotne, w 1602 i 1605 roku, w krakowskiej drukarni Łazarzowej dzieła kardynała Opusculum de processione Spiritus Santci [...]. Druga edycja Opusculi stanowi przekład na język polski ${ }^{16}$. Bessarion jest także bohaterem powieści historycznej Andrzeja Pawłowskiego Anielski Bessarion. Dzięki przybliżeniu postaci i środowiska osób znanych, mających wpływ na formację autora Crisias, możemy w sytuacji braku wiadomości o nim samym, umiejscowić go w określonym nurcie intelektualnym. Wiedza o istnieniu nielicznych odniesień do naszej kultury pozwala na postawienie hipotezy o tym, że utwory scriptoris minoris włoskiego quattrocenta - Hilariona z Werony - mogły być przedmiotem zainteresowania w dawnej Polsce.

13 Schmidt, „Die Crisias Des Hilarion von Verona”, 54.

14 Zob. Strobl, Karl der Grosse, 86.

15 Pozostałe utwory Hilariona zob. http://www.mirabileweb.it/risultati.aspx?csel=6\&psel=2 [dostęp: 11.06.2021]; https://data.cerl.org/thesaurus/cnp02221649 [dostęp: 11.06.2021].

16

Estreicher, Bibliografia polska, 519. 
Mówiąc o intelektualnej kondycji Hilariona, mamy na myśli jego miejsce wśród chrześcijańskich myślicieli, teologów, jak również twórców literatury pięknej, teoretyków poezji, którzy od pierwszych wieków po narodzeniu Chrystusa akcentowali intertekstualność i prowadzili dialog z antyczną tradycją głównie dla wyartykułowania jej funkcji paideutycznej (ad docendum). Przedstawiciele „chrześcijańskiej paidei", która stała się spadkobierczynią starożytnej, korzystali z tego wypracowanego systemu wychowania do kultury, tyle że w centrum tej kultury stawiali Chrystusa. Dość wspomnieć Klemensa Aleksandryjskiego, który wskazał antyczną proweniencję fragmentów Dziejów Apostolskich, Listu do Tytusa, Pierwszego Listu do Koryntian ${ }^{17}$. Podstawę greckiej paidei stanowiła poezja, a głównymi elementami tworzącymi poetycką fikcję były greckie mity. Wątpliwości co do wartości poezji przedstawiającej bogów nieróżniących się w swych słabościach od ludzi, najpełniej wybrzmiały w Państwie Platona. Jednak znaleziono sposób obrony mitologii. Zastosowanie w interpretacji mitów metody alegorycznej pozwoliło wskazać walory wychowawcze utworów Homera i Hezjoda. Quaestiones Homericae Heraklita Alegorety wskazują tę hermeneutyczną ścieżkę ${ }^{18}$, którą idą Filon, Orygenes, Kapadocjanie na Wschodzie i św. Augustyn - na Zachodzie. Wszyscy oni wskazywali na wartość dziedzictwa kulturowego Grecji dla chrześcijaństwa. Od średniowiecza niemniej popularny niż Homer i Hezjod był Wergiliusz, głównie jego Eneida. Ważnym ośrodkiem myśli, zajmującym się pogodzeniem antycznego dziedzictwa i prawd chrześcijańskiej religii, była Akademia Florencka, w której strukturach działał kardynał Bessarion największy orędownik zespolenia antycznej kultury z chrześcijaństwem i adresat Krysiady. O Bessarione czytamy, że „pod jego wpływem utrwaliło się przekonanie, że jedyną właściwą apologią chrześcijaństwa jest taka obrona, która by się opierała na uzgodnieniu Platona z Arystotelesem w duchu Plotyna"19. Wart zauważenia jest fakt, że w kolejnym stuleciu to Polak - Maciej Kazimierz Sarbiewski - dokładnie odpowiedział na ten postulat w teoretycznoliterackim traktacie De perfecta poesi i encyklopedycznym dziele - bajecznej teologii Dii gentium ${ }^{20}$.

Powyższe informacje wydały się niezbędne do zarysowania historycznego i kulturowego kontekstu, w jakim sytuuje się poemat Crisias. Tytuł powstał na wzór Iliady, Odysei czy Eneidy. Należy zwrócić w tym miejscu uwagę, że nazwę „krystiada” nosił gatunek chrześcijańskiego eposu stawiającego w centrum wydarzeń życie i mękę Chrystusa. Stał się popularny w XVI wieku, po publikacji Christiados libri sex Vidy w 1535 roku $^{21}$. Znacznie jednak wcześniejszymi eposami podejmującymi tematykę zbawczą są Evangeliorum libri IV Juwenkusa (III/IV w.) i Carmen paschale Seduliusza (poł. V w.). Z pewnością można by wskazać loci communes wczesnochrześcijańkich

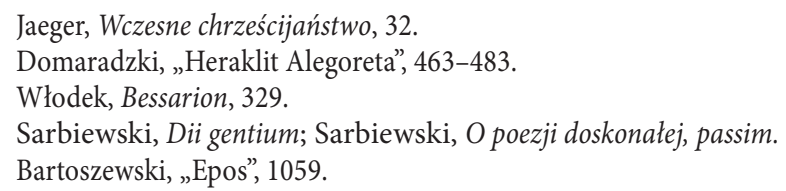


eposów i Krysiady Hilariona z Werony. Poza metrum jest to naśladownictwo stylu Owidiusza, Wergiliusza i Lukana. Tym, co zdecydowanie różni naszego autora od pisarzy wczesnochrześcijańskich, jest większa swoboda w zakresie wykorzystania źródeł inwencji, nasycenie tekstu elementami mitologicznymi i tematyka eschatologiczna.

\section{Relacje intertekstualne w I księdze poematu Crisias}

W dalszej części studium uwaga będzie skoncentrowana na I księdze, bardziej od dwóch pozostałych nasyconej obrazami, aluzjami i cytacjami znanymi z literatury antycznej. Utwór rozpoczyna się inwokacją do Muz, co oczywiście stanowi element przyjętej konwencji i jest zapowiedzią dialogu z antyczną tradycją. Dominantą stylistyczną w inwokacji jest patos. Słowa zapowiadają wydarzenia ważne, tajemnicze i złowrogie: „W tamto miejsce prowadź, Calliope, otoczona kręgiem siostrzanym./ $\mathrm{W}$ tamto miejsce śpiesz i uderzaj w dźwięczne struny kithary./ Teraz trzeba, by dzieło, co z natchnienia i z sił najprzedniejszych,/ w głębokości się wdarło i zabrzmiało dźwiękiem surowym./ Nie wdzięczne poematy, nie słodkie elegie wyśpiewaj./ Wielkie dzieło zaczynam uniesieniem boskim wiedziony,/ co wieszczów myśli prowadzi i sprawia, że głosy żarliwe/ wydają. Głębokości milczenia takie natchnienie rozrywa” (w. 1-5). Seduliusz w swoim Carmen paschale prosi Boga, nie Muzy, o przewodnictwo i pomoc w akcie twórczym. Jest to zrozumiałe wobec podjętej przez autora tematyki. Zestawienie z inwokacją Krysiady pozwala wysnuć wniosek, że autorzy reprezentowali decorum swojego czasu. Badacz poezji wczesnochrześcijańskiej twierdzi, że „przeciwstawienie sobie poezji pogańskiej i chrześcijańskiej jest pierwszym zalążkiem toposu, który odtąd już często będzie spotykany w literaturze" ${ }^{\text {"22 }}$. W prezentowanym utworze nie ma tego przeciwstawienia. Jest koegzystencja i o niej także możemy powiedzieć, że stanowi topos obecny w literaturze. Powiązanie elementów chrześcijańskich i pogańskich nie nosi znamion nieprawomyślności. Cytacje, reminiscencje antyczne stanowią narzędzie, które służy do przedstawienia chrześcijańkskich treści. Uroczysty zwrot do Muz odsyła czytelnika do antycznej teorii poezji i boskiej proweniencji tej ostatniej ${ }^{23}$. W warstwie leksykalnej odnajdujemy w samej inwokacji liczne aluzje do Eneidy Wergiliusza - zwrot do Calliope $(9,525)$, przekonanie o misji twórczej $(8,441)$, wyrażenie silentia alta i w jego sąsiedztwie użyte formy cogit i rumpit (9, 63-4). Przedstawienie wydarzeń mających poprzedzić Sąd Ostateczny wymaga właściwej formy, odpowiednio dobranych słów. Będzie to pieśń prawdziwa o znakach zesłanych przez Wszechmocnego. Znaki będą przerażające, dzieło nie może być zatem „słodkim poematem” (dulces elegi, grata poemata). Pierwszym znakiem będą

22 Wójtowicz, wstęp do Carmen Paschale Seduliusza, 14.

23 Por. Platon, Jon 534 c; M.T. Cicero, Tusculane disputationes I, 26, 64. 
wojny, niemające niczego wspólnego z walką o sprawiedliwość, których przyczyn i skutków nie da się wskazać. Anomalią w przyrodzie będą występujące z brzegów rzeki bryzgające krwią. Jest tu aluzja do mitycznego Flegetonu - płonącej rzeki krwi, o której wspomina Homer w Odysei (10, 513), Wergiliusz w Eneidzie (6, 265). Zważywszy fakt, że autor uczynił sprawczynią tych klęsk Alekto, także kolejne prezentowane obrazy należy powiązać z mitologią. Alekto jest jedną z powstałych z Gai użyźnionej krwią Uranosa Eryń o wężowych włosach. Wiemy o nich z Teogonii Hezjoda (w. 185). Imię bogini ma znaczenie „nieprzebłagana”. W naszym poemacie wychodzi ona z czeluści piekielnych, idzie przez miasta i sączy zielony żmijowy jad w gnuśne umysły mężów, rozpalając gniew i nienawiść. Ów żmijowy jad stanowi metaforę podżegania. Obraz został przeniesiony z VII księgi Eneidy, kiedy to Alekto ciska w pierś Amaty - żony Latynusa żmijowy włos, by ta niepohamowana w gniewie przeszkodziła oddaniu Lawinii za żonę Eneaszowi. Alecto pojawia się w Metamorfozach Owidiusza. Te motywy wykorzystał też Dante, opisując VI i VII krąg swojego piekła. Alekto wraz z siostrami Megerą i Tyzyfoną zajmują najgłębsze czeluście piekielne. Do płynącej w VII kręgu rzeki krwi wrzucony jest „kto przez gwałt drugim przyczyną był szkody" (w. 1555). Podobieństwo w sposobie adaptacji antycznych elementów przez naszego autora i Dantego może wynikać z czytelniczej formacji Hilariona, który najpewniej znał Boska komedię. Warto w tym miejscu zaznaczyć, że w czasie, w którym powstała Crisias bardzo ważne miejsce w dyskursie teoretycznoliterackim, zajmującym członków Akademii Florenckiej, a wśród nich adresata naszego eposu Bessariona, zajmowały zagadnienia intertekstualności. Imitacja antycznych wzorów, alegacje, aluzje, cytowania - były to środki wykorzystywania wspólnego dobra w celu wykazania się erudycją autorów, którzy dzięki twórczemu przetworzeniu nadawali rzeczom znanym indywidualne cechy. Nasz autor z każdą kolejną rewokacją utworów starożytnych w swoim eposie wpisuje się zatem w renesansową teorię emulacji.

Kolejna mitologiczna postać Lyssa pojawia się w Krysiadzie jako Furor - odpowiednik w mitologii Rzymian. Jest w naszym poemacie uosobieniem gniewu - prowodyrem bratobójczych walk poprzedzających Sąd Ostateczny. Obraz postaci z zakrwawionym obliczem przeniesiony został z Tebaidy Stacjusza (Furor vultu cruento 7,52). W Crisias o Furorze czytamy, że będzie dobijał się do domów, pożerał swoje ofiary, aż do krwawych wymiotów. Tę okrutną wizję poprzedza skarga: „O, jak bardzo nieszczęsny, nazbyt godny pożałowania to czas" (w. 23). Słowa lacrimabile tempus najpewniej stanowią aluzję do Tristia Owidiusza (V, 12, 1).

Autor konsekwentnie, poprzez zastosowanie czasu przyszłego, utrzymuje konwencję wizji, z naturalistycznymi szczegółami kreśli czekającą ludzi przyszłość: porzucone na gościńcach, rozszarpywane przez drapieżne ptaki ludzkie zwłoki, których bliscy nie będą mogli pochować. Inne ciała będą unoszone w nurtach rzek i staną się pokarmem dla ryb o przepastnych gardzielach. Ten sui generis akwatyczny motyw stworzył okazję do przywołania Skylli. Nawet morski potwór opisany w Odysei nie był świadkiem i sprawcą tylu krwawych zbrodni - twierdzi autor - ile będzie miało 
miejsce podczas wieszczonych bitew przez Sądem Ostatecznym. Okrutne prorocze wizje porównywane są do obrazów, które utrwalił Plutarch w Żywotach sławnych mężów ${ }^{24}$. Autor Krysiady wymienia Gajusza Mariusza i wykorzystuje w opisie przewidywanych krwawych starć fragmenty krajobrazu po bitwie z Cymbrami pod Vercellae. Nie można też wykluczyć, że współczesnym źródłem inwencyjnym były dla Hilariona wiersze Piusa II. Piccolomini w bardzo podobny sposób prowadzi dialog $\mathrm{z}$ tradycją antyczną w napisanym heksametrem utworze skierowanym przeciwko Turkom Pro ingenii exercitatione ${ }^{25}$.

Hilarion opisuje pełne okrucieństwa wojenne sceny z udziałem kobiet ciężarnych, z których łon wyrywane są dzieci, matek opłakujących potomstwo, młodych panien, które krótko przed planowanym zamążpójściem, są gwałcone i zniewalane. Podobne opisy znajdujemy w heksametrach Eneasza Sylwiusza Piccolominiego. Zbieżność, jeśli weźmiemy pod uwagę wszystkie wspomniane już w niniejszym szkicu informacje o środowisku kulturalnym włoskiego quattrocenta, wydaje się nieprzypadkowa. W szczególnie przejmujące obrazy obfituje część I księgi Crisias (w. 42-56) z opisem cierpienia matek opłakujących martwe dzieci przytulane do łona. Bezradność i ból każą z jękiem skierowanym ku gwiazdom wzywać okrutnych bogów. „Clamorem super astra ferent, divosque vocabunt/ Crudeles, totumque implebunt aethera planctu" (w. 50-51). Wyeksponowany topos matczynej miłości i utraty dziecka, przywodzący na myśl Matkę Boleściwą, stwarza sposobność do przywołania kolejnej mitologicznej postaci - Cerery. Matki będą - tak jak Cerera - poszukiwały zaginionych córek. Wołania pozostaną jednak bez odpowiedzi. Imaginarium bratobójczych walk powstaje w tekście Krysiady dzięki przypomnieniu mitu tebańskiego. Ten ostatni, znany głównie z tragedii Sofoklesa Antygona, w którym walczą przeciw sobie bracia Polinejkes i Eteokles, kończy się śmiercią siostry, która wbrew prawu grzebie zwłoki zmarłego Polinejkesa. Refleks tego mitologicznego wydarzenia także znajdujemy w Crisias. Niemożność urządzenia pogrzebu zmarłym towarzyszyć ma wojennym rzeziom. „Non aderit, caeso moestas qui reddat amico/ Exequias et lecta manu tegat ossa sepulchro" (w. 35). Ze względu na wagę pochówku w chrześcijaństwie i znaczenie grobu człowieka, który stanowi jego domus aeterna ${ }^{26}$, obraz wydaje się znaczący.

Zaburzone relacje rodzinne, polegające na zrywaniu więzi, zaniku troski o najbliższych krewnych, łamaniu małżeńskich zobowiązań, lekceważeniu kwestii moralnych, zostają w Krysiadzie zobrazowane także poprzez antyczne rewokacje i aluzje. Oczywiste jest nawiązanie do czwartego wieku ludzkości z Metamorfo $z^{27}$. Przypomi-

24 Plutarch, De viris illustribus (Brożek, 616).

25 „Rapiuntur ab ubere matrum/ infantes, amplexa virum matrona gementem/ eripitur ferro, sancti ceduntur ad aras/ presbyteri, nocuit claro de sanguine nasci,/ nobilitas mactata foro, cervice revulsa/ ora cadunt multoque iacent immerse" (Piccolomini, Carmina varia, 1, 2, v. 104-109.)

26 Forstner, Świat symboliki chrześcijańskiej, 368.

27 Np. werset o chęci skrócenia życia ojca (I, 148-149): „Filius ante diem patrios inquirit in annos: victa iacet pietas,/ Filius, impatiens tam longam ferre senectam,/ Patris in exitium veniet crudelis" (73-74). 
na Hilarion mit o klątwie Pelopidów, w którym po licznych epizodach związanych z walką o władzę synów Pelotreusa i Tiestesa, ten drugi zostaje poczęstowany przez brata posiłkiem sporządzonym $\mathrm{z}$ ciał swoich synów. Z imienia przywołana jest także Medea - najbardziej znana dzieciobójczyni starożytności. W prezentowanym eposie porównane są do niej matki, które zsyłają do tartaru dzieci ssące ich piersi. Skoro tym miejscem pobytu po śmierci ma być tartar, możemy domniemywać, że chodzi w tekście eposu o dzieci jeszcze nieochrzczone, czyli takie, których dusze, według toczących się w średniowieczu dyskusji, będą pozbawione obecności Stwórcy ${ }^{28}$. Szaleństwo, cudzołóstwo, niszczenie małżeńskich więzów - to występki przeciwko moralności nieobce także postaciom mitologicznym. Najpewniej pojawiające się w tekście aluzje odsyłają do historii dwóch sióstr - Klitajmestry i Heleny. Do pierwszej odnoszą się słowa: „Saeva ob adulterium coniunx de morte mariti/ Consultans, sancti violabit foedera nexus” (w. 77-78), do drugiej: „Hinc fugiens primoque relicto coniuge, laeta/ Externum inveniet ducetque scelesta secundum" (w. 81-82).

Nad przebiegiem opisanych klęsk, które słońce oświetli ponurym światłem (torvo lumine v. 75), czuwać będzie Alekto.

\section{Klęska głodu}

Kolejny „akt” należeć ma do Fames. W opisie klęski głodu źródłem inwencji dla naszego autora są Metamorfozy Owidiusza. Wergiliusz także wymienia Głód (Fames) wśród postaci stojących w przedsionku królestwa podziemia (VI, 276). W Przemianach passus o tej mniej znanej córce Nocy pojawia się w kontekście kary, jaką ponieść ma Eryzychton za wycięcie świętych dębów z gaju Cerery (VIII, 770). Ta wysyła jedną z nimf, by z mroźnej ziemi Scytów przywiodła do grzesznika Głód, żeby spowodował $\mathrm{u}$ Eryzychtona niezaspokojone pragnienie jedzenia. Hilarion $\mathrm{z}$ Werony adaptuje Owidiuszowe motywy. Rozkazy Fames wydaje w Krysiadzie jej „tartaryjska siostra” Alecto, która wesoła (laeta) przybywa do domu siostry. Zaproszenie do działania wyrażone zostaje słowami „Salve, cara soror, menti gratissima nostrae,/ Pone animos moestos et mecum gaudia sume" (w. 92-93). Autor, parafrazując tekst Owidiusza, poświęca kilka wersów opisaniu ojczyzny ponurej bogini. To kamienista scytyjska dolina ograniczona zmarzniętymi brzegami (w. 85-87). Miejsce jest nieurodzajne, bez darów Cerery i Bakchusa - imiona bogów stanowią metonimie plonów. Tak jak w opisie Owidiusza Głód (Fames) występuje w towarzystwie Bladości (Pallor) i pasie się mizernymi, ledwie widocznymi ziołami. Także parafrazując fragment Przemian (VIII, 799-808) daje poeta charakterystykę ohydnej postaci (w. 87-95). Głód ma zamiast brzucha ziejące pustką miejsce, przez które można dostrzec wnętrzności, 
próchnicę w gardzieli, najeżoną szczecinę, a jego kości zdają się wydłużone z powodu nadmiernej chudości. Bardzo plastyczny opis zdaje się pełnić funkcję imaginis agentis w myśl następujących słów traktatu Rhetorica ad Herennium:

Imagines igitur nos in eo genere constituere oportebit, quod genus in memoria diutissime potest haerere. Id accidet, si quam maxime notatas similitudines constituemus; si non multas nec vagas, sed aliquid agentes imagines ponemus; si egregiam pulchritudinem aut unicam turpitudinem eis adtribuemus ${ }^{29}$.

Uosobiona Fames na rozkaz Alekto ogołoci pola, zniszczy zasiewy, zmusi ludzi do jedzenia ukrytych w ziemi korzeni i żołędzi. Szczególnie dramatycznie opisana została spowodowana głodem konieczność pozbywania się zwierząt, które jako fratres minores, dotychczas pomagały ludziom wedle potrzeb właścicieli: zginie koń, który z panem uczestniczył w wyprawie wojennej; zginie bydło pracujące na roli, straci życie osioł ciągnący wóz z towarami handlarza. W końcu, skoro nie będzie już żadnych możliwości pozyskania pożywienia, ,wszyscy wyzioną duszę nie odniósłszy rany" (animam sine vulnere fundent): ojcowie zobaczą śmierć dzieci; niemowlęta, tuląc się do bezmlecznych piersi, odejdą wraz z matkami (w. 115-134). Proh dolor! - wykrzyknie wszechwiedzący narrator - prorok czasów końca. By opowieść uwiarygodnić i jednocześnie uzyskać efekt hiperboli, porównuje ów czas głodu do historycznych wydarzeń, z przestrogą, że tamte klęski głodu i towarzyszące im wydarzenia wobec tych mających nadejść przed Sądem, były o wiele mniej dotkliwe. Autor buduje wypowiedź z dbałością o retoryczne uporządkowanie wywodu. W wyliczaniu kolejnych wydarzeń stopniuje napięcie dzięki zastosowaniu klimaksu. Wymienia najpierw głód, który miał według sennej wizji faraona nawiedzić Egipt, ale dzięki dokonanej przez Józefa interpretacji snu, udało się uniknąć skutków klęski. To oczywista aluzja do Księgi Rodzaju (41,25-36). Siedem chudych i brzydkich krów ze snu władcy i siedem pustych kłosów zapowiadało siedem lat głodu. Kolejne wspomniane wydarzenie wiąże się z postacią króla Aramu Ben - Hadada. Tu także przedstawione egzemplum odsyła do Biblii. W opisanym w Drugiej Księdze Królewskiej głodzie w oblężonej Samarii (2 Krl 6-24) - wzrost cen za głowę osła i nawóz gołębia wyobrazić ma rozmiar klęski. Autor najpewniej korzystał z Wulgaty, bo posługuje się imieniem Benadab i pisze o gołębim nawozie. Słowa przetłumaczone przez św. Hieronima jako gołębi nawóz oznaczają w tekście hebrajskim ćwiartkę kaba dzikiej cebuli. W dalszej części Drugiej Księgi Królewskiej jest mowa o spożyciu ciała młodzieńca. Nasz autor najwyraźniej rozmyślnie nie pisze o tym biblijnym wydarzeniu, bo stopniując napięcie, kwestię kanibalizmu poruszy później. Przywołuje i komentuje jako mniejszy od mającego nadejść, opisany w Pierwszej Księdze Królewskiej (17,1-2) głód, spowodowany dwuletnią suszą - wynik nałożenia klątwy przez Eliasza na króla Achaba.

Marx, Rhetorica ad Herennium, III, XXII, 37. 
Źródłem następnego exemplum okazuje się De bello Iudaico libri septem Józefa Flawiusza. Przekonując, że głód, który dotknął mieszkańców Jerozolimy, był mniejszy niż ten wieszczony w Crisias, Hilarion przywołuje przejmujący przykład: „Illa etiam inferior, Solymos quae afflixit et urbem/ Eruit, infelix quo tempore mater ad acta/ Visceribus propriis immergere viscera nati” (w. 144-146). Czytając te wersety, zauważamy zabiegi instrumentacyjne, jak również udaną w naszej opinii peryfrazę środki obrazowania wzmagające ekspresję. W filologicznym przekładzie fragment brzmi: „Ten [głód] mniej był dotkliwy, który pogrążył i zburzył Jerozolimę, kiedy to matka nieszczęsna została zmuszona, by swoje wnętrzności napełnić wnętrznościami synka". Wydarzenie zostało opisane przez Józefa Flawiusza. Dotyczy zdobycia Jerozolimy w 70 roku. Kontekst tej makabrycznej zbrodni zawiera pewne usprawiedliwienie działania matki, która „rebus adversis contra naturam excitatur”. Kobieta zjada niemowlę, chcąc zapobiec jego życiu w niewoli Rzymian ${ }^{30}$. Ten przykład szokuje czytelnika i zostaje w pamięci. Jest to pierwsze egzemplum historyczne - spoza Biblii i spoza mitologii; następne także dotyczą podbojów Rzymian. Mamy najpewniej podaną za Plutarchem informację o Marku Furiuszu Kamillusie i klęsce głodu, która zdziesiątkowała Rzymian podczas wojny z Galami w 387 roku przed Chrystusem. Źródłem kilku bardzo drastycznych opisów jest Factorum et dictorum memorabilium libri novem Waleriusza Maksymusa. Przedstawione w Krysiadzie epizody związane z głodem (w. 153-170), miały miejsce, według przekazu historyka, podczas oblężenia Kapui w przebiegu II wojny punickiej. To wówczas jeden z mieszkańców Kapui miał zjeść śmierdzące myszy i rozmoczone w wodzie skóry zdjęte z tarcz; mieszkańcy Preneste, by zaspokoić głód, płacili niemałe sumy za myszy; Kreteńczycy oblężeni przez Metellusa w 69 roku mieli, powodowani pragnieniem, pić mocz swój i swojego bydła. Oblegani przez Scypiona Afrykańskiego II Numantynowie zostali zmuszeni przez najeźdźcę do zjadania zakrwawionych fragmentów ciał poległych. I w końcu pojawia się aluzja do wojny sertoriańskiej i oblężenia Calagurris przez Pompejusza i Metellusa w 76 roku przed Chrystusem. Obrońcy twierdzy zjadali dzieci powodowani głodem, ale wcześniej wykorzystywali żony i dzieci jako żywe tarcze. Sczególnie makabrycznym szczegółem jest to, że solili ludzkie mięso ${ }^{31}$. Wrażenie potęguje Hilarion poprzez użycie retorycznych pytań:

Quid Praenestinos referam, quos barbarus ille Hannibal oppressit tantum, tantumque refregit,

Ut nummis videas murem venire trecentis?

Quid Cretas, longa qui ex obsidione Metelli

Urinam propriam miseri pecudumque bibere?

\footnotetext{
30 Flavius, De bello Iudaico (lib. VI, cap. III, 4), 336.

31 Przykłady, o których mowa, mają następujące lokalizacje: Valerius Maximus, Factorvm et dictorvm memorabilivm libri novem VII 6, 1 - VII 6, 3.
} 
Quidque Numantinos, quos mandere dentibus atris

Humanas carnes artusque vorare cruentos

Scipio crudelis consumptis omnibus egit?

Quid tandem memorem crudos scaevosque parentes

Callaguritanios, quos dum convincere Magnus

Obsidione parat, duros belloque feroces

Omnibus absumptis ad dulcia pignora versos

Uxoresque ferunt, quo se quoque longius ipsos

Servarent, carnes sale conspersisse prophanos? (w. 157-170).

Ostatnie z egzemplów jest najbardziej drastyczne. Dotyczy nie tylko kwestii głodu i kanibalizmu jako ekstremalnego zachowania w wyniku braku żywności, ale też szczególnie haniebnej profanacji zwłok. Cały fragment I księgi Krysiady, w którym przywołuje autor obrazy głodu - czy to te utrwalone w mitologii, czy w źródłach historycznych - pełni kilka funkcji. Imagines agentes mają pozostać w pamięci. Ten środek retoryczny stosowany jest w ten sam sposób, w jaki wykorzystywali go średniowieczni kaznodzieje. Konstruując wywód wyraźnie, podobnie zresztą jak $\mathrm{w}$ całym poemacie, czerpie Hilarion $\mathrm{z}$ wiedzy $\mathrm{w}$ zakresie ars praedicandi $\mathrm{w}$ funkcji $a d$ docendum ${ }^{32}$. Inne narzędzia stosowane według reguł retoryki i poetyki - wśród nich personifikacja, klimaks, pytania retoryczne, hiperbole, aluzje, parafrazy pełnią funkcję perswazyjną, ale też charakteryzują relację nadawczo-odbiorczą: by właściwie odczytać tekst, trzeba „odszyfrować” przestrzeń intertekstualną, w jakiej autor się porusza. Tym kodem jest antyk: mitologia, poezja, historia. Oczywiście konkluzja tego fragmentu tekstu, refleksja o mającym przyjść głodzie, pojawiająca się na koniec historycznych egzemplów - „ludzie podczas doświadczenia klęski głodu doznają i ujrzą rzeczy bardziej od tych okrutnych” (w. 171-172), jest retorycznym dodatkiem, bo wydaje się, że autor dotarł w tekście do horyzontu wyobraźni odnośnie do skutków powodowanych brakiem pożywienia.

W kolejnym akcie zniszczenia rolę odegra największa z Furii - Tisiphone. Cały fragment poświęcony działaniu Furii inspirowany jest najpewniej Przemianami Owidiusza. W czwartej księdze Tisiphone zjawia się na wezwanie Junony, by wraz z siostrami zadbała o obalenie rodu Kadmosa. Według Owidiuszowego przekazu (IV, 510-520) Furia dysponuje jadem powstałym ze śliny Cerbera i trucizny, którą dysponowała jego matka Echidna. Te substancje pomieszała Furia z krwią i cykutą. Powstała mikstura unicestwiała to, co materialne i wzniecała wszelkie ohydne instynkty i zachowania, niszczące relacje w ożywionym świecie. Tisiphone działała poprzez żywioły: ogień, wodę i powietrze. Te wątki zapożyczył Hilarion. Morowe powietrze powodowało zagładę na ziemi, potop - na morzu, ogień towarzyszyć miał katastrofom kosmicznym. Trucizna, którą Furia pokropi (sperget) ziemię, zanim sprowadzi

32 Por. Witkowska, „Miracula średniowieczne”, 186. 
na ludzi śmierć, zburzy porządek w naturze. Wywód prezentujący poszczególne etapy unicestwiania jest jakby odwróconym obrazem stworzenia świata. Zagłada uniemożliwi człowiekowi podejmowanie zadania „czynienia sobie ziemi poddanej”, spowoduje niemożność podjęcia działań, mających u podstaw koegzystencję ludzi ze światem przyrody. „Leniwa śmierć” (iners letum) dosięgnie przy żłobie konia uczestniczącego wcześniej w wojennych tryumfach; wół padnie przy pracy. A pomiędzy ludźmi paradoksalnie im więcej miłości, solidarności, bliskości, tym większe żniwo śmierci powodowanej wzajemnym zarażaniem się morowym powietrzem. Trupy będą leżeć jak owoce pod drzewem albo strząśnięte żołędzie z dębu (w. 204-205).

\section{Kosmiczne wizje}

Katastrofy prezentowane w dalszej części Krysiady (w. 207-300), w których opisie autor wydaje się najwięcej czerpać z apokryfów apokaliptycznych (scilicet wyrocznie Sybilli, Czwarta Księga Ezdrasza) i Janowego Objawienia, stanowią fascynujące imaginarium. Wplecenie bajecznych mitologicznych postaci działających na rozkaz Furii podtrzymuje przyjętą konwencję. Estetyka tekstu w warstwie elokucji: leksyka wyrażająca ruch, światło, kolor, figury słów i myśli, wspomaga wyobraźnię. Hilarion wprowadza dość tajemniczą postać Phoibe, która w tekście jest przedstawiona jako contraria nitido fratri (w. 209). Być może to Apollon - Phoibus kryje się pod tą peryfrazą, choć nie potwierdzają tego pokrewieństwa źródła, wedle których Febe jest babką Feba. Jednak zbieżność foniczna imion i konotacje obojga bóstw z wyrocznią pytyjską pozwalają na tę hipotezę $e^{33}$. Wśród wymienionych w eposie postaci mitologicznych rządzących prawami natury są Sol i Luna. Jest też Eol, który uwalnia wszystkie wiatry. Przesuwające się po niebie komety, księżyc pokryty krwawymi plamami, stłumione światło słońca, ciemny blask gwiazd, nieustanne deszcze - to typowe obrazy, które według dawnych przepowiedni zwiastowały jakąś zmianę. Wymienia je także Hilarion, dzieląc się z czytelnikiem co kilka wersów retorycznym refrenem: „Jakiż strach ogarnie śmiertelnych!” (w. 218). W opisie zadbał autor o audiosferę. Dźwięk wydobywający się $\mathrm{z}$ huczącego nieba porównuje do wojennego szczęku broni. Upersonifikowana ziemia, która dotąd nie znała przejawów takiego niszczycielskiego szału, wyda przerażające ryki: „Et tellus, tanti non inscia vasta furoris,/ Mugitus dabit horrendos motusque frequentes" (w. 223-234). Erupcja Etny zniszczy świątynie bogów, a góry zrodzą przedziwne monstra. Ich opis przywodzi na myśl średniowieczne miniatury zdobiące Specula humanae salvationis. Postaci

33 Febe, jako córka matki Ziemi, miała być głosem z samego wnętrza Gai. Mężem Febe był Polos - oś nieba, ich córką była Leto, Apollo zaś synem Leto, którego greckie imię Phoibos znaczy - „jaśniejący” (Aeschylus, Eumenides 1nn [Srebrny, 323]). 
skrzydlatych, pełzających, hybrydycznych tworów o niszczycielskich zapędach, mają cechy mitologicznych monstrów. Powiązanie z erupcją Etny może wskazywać na postać Tyfona i „zwierzyniec” opisany przez Owidiusza w Przemianach (V, 320-336; 349-364) w związku z batalią odbytą przez smoka z bogami. W opisie Nazona przygniecione Etną monstrum, chcąc się uwolnić, wywoływało trzęsienie ziemi. Fraza „parturient montes” została przejęta z Ars poetica Horacego ${ }^{34}$. Obrazy pojawiające się w tekście Krysiady zmieniają się dynamicznie, czemu sprzyja ukształtowanie metryczne wiersza z przewagą stóp daktylicznych w wersach. Walki upersonifikowanych wiatrów (Eurus, Notus, Africus) mają na celu doprowadzenie do morskiej katastrofy, skutkującej otwarciem się piekła, którego metonimią jest w tekście Dis. „Inde mari incumbent, vastosque a sedibus imis/Attollent fluctus, caelum terramque revolvent Ad Ditem” (w. 241-243). Żeglujący po morzach nie będą w stanie rozeznać położenia, „wielka burza nie pozwoli usłyszeć głosu morza” (w. 251). Tu oczywistym źródłem inwencyjnym jest I księga Eneidy. Eol na prośbę nienawidzącej Eneasza Junony wywołuje morską katastrofę (I, 50-125). Similia znajdujemy zarówno w środkach obrazowania, jak i w leksyce. Jednak powiązanie w tekście katastrofy morskiej z katastrofą na lądzie, peryfrastyczny opis tsunami - „rimis maris unda meavit” (w. 279) - pozwala na postawienie hipotezy o aluzji do trzęsienia ziemi w Antiochii w 115 roku, opisanego przez Kasjusza Diona w Historii rzymskiej (LXVIII, 24-26). Ostatnim obrazem w I księdze Krysiady jest miotany burzą żaglowiec. Ścierajace się wiatry wyniosą go do samego nieba, skąd ze względu na rozpadliny ujrzy Acheront rzekę smutku w Hadesie, po czym zostanie wtłoczony w ogromną otchłań. Wichry rozerwą żagle, rozszczelnią kadłuby. Zmaganiom towarzyszyć będzie kompletna ciemność, przerywana jedynie rozbłyskiem piorunów. Najpewniej ten rozbudowany obraz miotanego przeciwnymi wiatrami okrętu, którego załoga raz widzi piekło, raz niebo i błądzi w zupełnej ciemności, ma znaczenie symboliczne. Topos żeglugi jako alegorii ludzkiego życia był obecny tak w kulturze starożytnej, jak i chrześcijańskiej ${ }^{35}$. Przewoźnik w Hadesie - Charon, zmierzający ku swojemu przeznaczeniu Odyseusz i Eneasz, to oczywiste pojawiające się konotacje. Liczne, poddające się alegorycznej egzegezie opisy żeglugi odnajdujemy w Biblii. Do najbardziej wymownych należą intertekstualne rozdziały 27 i 28 Księgi Ezechiela o upadku Tyru. Komentarze Ojców Kościoła podkreślają eschatologiczny wymiar tekstu ${ }^{36}$. Patrząc na ten końcowy fragment I księgi Krysiady z perspektywy filologa, można uznać tekst za interesujący z uwagi na komentarz wszystko wiedzącego narratora. Komentarz dotyczy sfery ludzkich odczuć: najtrudniej będzie ludziom stawić czoła strachowi: „mortis erit prior ipse metus, maior quoque morte” (w. 182). Homeryckie porównanie ma pomóc wyobraźni: „Jak obywatele zwykle drżą, kiedy wrogowie podkopują

\footnotetext{
34 Horatius, Ars poetica (Jurewicz, 139): „Parturient montes, nascetur ridiculus mus”.

35 Forstner, Świat symboliki chrześcijańskiej, 425-426.

36 Zob. Hieronymus, In Ezechielem, 115-140.
} 
się pod obwarowania, a te się chwieją i każdy spodziewa się tortur i śmierci z rąk wroga, i ten właśnie strach jest większy od samej śmierci, tak nieszczęśni żeglarze, świadomi swego losu, będą drżeć i wołać bogów" (w. 283-289). Bogowie pogan jako adresaci modlitw, nie chrześcijański Bóg, pojawiają się raz jeszcze: „Żałosny tłum zaniesie lament do gwiazd i będzie wołał bogów" (w. 297). Kolejny wers oznajmia kres: Wszechmocny Ojciec rozżalony roztrzaska okręt i pogrąży wszystko w głębinach -, ,quos Pater Omnipotens tandem miseratus ab alto/ fracta puppe omni demerget in aequora cunctos" (w. 298-299). Gramatycznie zaimek quos odnosi się w tekście do deos, choć prawdopodobnie został użyty jako constructio ad sensum i wskazuje na grupę żeglujących nieszczęśników (caterva). Nie można jednak wykluczyć, że jest to celowa dwuznaczność: prawdziwy Bóg zatapia bogów pogan wraz z wznoszącymi do tych bogów modły.

\section{Zakończenie}

W niniejszym studium podjęto próbę wskazania relacji intertekstualnych w Krysiadzie, źródeł inwencyjnych poematu, similiów, środków obrazowania literackiego, funkcji przekazu. Analiza tekstu pozwala na stwierdzenie, że cały utwór Hilariona z Werony, nie tylko zaprezentowana I księga Crisias, nosi znamiona gry pomiędzy nadawcą i adresatem - Bessarionem. Tę intuicję potwierdza wspomniane już enkomion skierowane do kardynała, w którym akcentuje się erudycję hierarchy w zakresie wiedzy o kulturze grecko-rzymskiego antyku. Rozpoznanie aluzji mitologicznych, faktów historycznych, cytacji, parafraz, leksyki pochodzącej z antycznych utworów, stanowiło wyzwanie dla czytelnika, ale taka kompozycja utworu nobilitowała także autora. Intelektualna formacja obydwu sprzyjała porozumieniu. Współczesny badacz uważa, że kategoria lektury jest

[...] podstawową kategorią operacyjną w klasycznym dyskursie retorycznym. Będąc fundamentem inventio należy do porządku „pretekstowego", poprzedza mowę retoryczną, dostarczając jej materiału perswazyjnego, który następnie poddawany jest inwencyjnym wyborom i selekcjom. Bez lektury pytanie retora lub poety musiałoby pozostać bez satysfakcjonującej ich odpowiedzi ${ }^{37}$.

Stosowane przez Hilariona środki retoryczne, takie jak eksklamacje, hiperbole, porównania z wykorzystaniem egzemplów, sprzyjają patosowi wypowiedzi, jej dramatyczności. Imaginarium eschatologiczne, którego źródłem są znane utwory antyczne, głównie epopeje Homera i Wergiliusza, Metamorfozy Owidiusza, ale też

37 Rysiewicz, Zagadnienia retoryki, 39. 
dzieła starożytnych historyków, najpewniej wywoływały u adresata - erudyty z Akademii Palatońskiej - déjà lu. Nie można jednak lekceważyć paideutycznego celu, któremu de facto podporządkowane są erudycyjne wywody. Swoim eposem wpisuje się Hilarion w dość popularny w Europie XV wieku nurt poezji eschatologicznej aktualizowanej głównie w formie hymnów ${ }^{38}$. I księga poematu Crysias, inkrustowana antycznymi elementami, mogłaby być potwierdzeniem tezy wygłoszonej półtora wieku później przez Gallucjusza.

Mowa zaś chrześcijanina nie powinna być podobna do mowy Muz, które trzymają kitharę i flet, ale Pallady, która uzbrojona jest w żelazo i pociski, to znaczy taka, która ujarzmia umysły słuchaczy surowością, a nie schlebia i roztkliwia przyjemnością ${ }^{39}$.

\section{Bibliografia}

Aeschylus, Eumenides, tł. pol. S. Srebrny: Ajschylos, „Eumenidy”, Antologia tragedii greckiej (opr. S. Stabryła) (Kraków: Wydawnictwo Literackie 1989).

Augustinus, De civitate Dei. Libri XI-XXII (red. B. Dombart - A. Kalb) (Corpus Christianorum Series Latina 48; Turnhout: Brepols 1955).

von Bardenhewer, O., Patrologie (Freiburg im Breisgau: Herder 1894).

Bartoszewski, K., „Epos”, Encyklopedia katolicka (Lublin: TN KUL 1985) IV, 1059.

Blume, C. (red.), Pia dictamina (Analecta Hymnica Medii Aevi 33; Leipzig: Reisland 1899).

Cassius Dio, Historia Romana, tł. ang. E. Cary: Dio's Roman History (Loeb Classical Library 32, 37, 53, 66, 82-83, 175-177; Cambridge, MA - London: Harvard University Press 1954-1960) I-IX.

Codex Vaticanus Urbinas Latinus 737, https://digi.vatlib.it/view/MSS_Urb.lat.737 [dostęp: 11.06.2021].

Dante Alighieri, Boska komedia (tł. J. Korsak) (Warszawa: Olgebrand 1860).

Domaradzki, M., „Heraklit Alegoreta i filozoficzne znaczenie starożytnej egzegezy Homera”, Ruch Filozoficzny 68/3 (2011) 463-483.

Enee Silvii Piccolominei postea PII PP. II Carmina (red. A. van Heck) (Città del Vaticano: Biblioteca Apostolica Vaticana 1994).

Estreicher, K., Bibliografia polska (Kraków: Drukarnia Uniwersytetu Jagiellońskiego 1891) XII.

Forstner, D., Świat symboliki chrześcijańskiej (Warszawa: Instytut Wydawn Pax 1990).

Gallucius Sabinus, T., Orationum volumina duo (Coloniae: apud Ioannem Crithium sub signo Galli 1618).

Granat, W., Ku człowiekowi i Bogu w Chrystusie. Zarys dogmatyki katolickiej (Lublin: TN KUL 1974) II.

38 De Extremo Iudicio, Analecta Hymnica Medii Aevi, 294-296; zob. też przypis 8 niniejszego studium.

39 Gallucius Sabinus, Orationum volumina duo, 133: „Christiani autem hominis orationem non debere similem esse Musis, quae citharam ac tibias tenent, sed Palladi, quae ferro ac telis armatur, hoc est eam, quae severitate audientium animos premat, non deliniat ac molliat voluptate". Przekład własny. 
Hieronymus, In Ezechielem Pars 2, https://www.documentacatholicaomnia.eu/04z/z_03470420_Hieronymus_In_Ezechielem_Pars_2_LT.pdf.html [dostęp: 11.06.2021].

Horatius Flaccus Quintus, Epistulae. Ars poetica, tł. pol. O. Jurewicz: Kwintus Horacjusz Flakkus, Gawędy. Listy. Sztuka poetycka (opr. O. Jurewicz) (Warszawa: PWN 2000).

Jaeger, W., Wczesne chrześcijaństwo i grecka paideia (opr., tł. K. Bielawski) (Bydgoszcz: Homini 1997).

Josephus Flavius, De bello Judaico libri septem (interpret. R. Aquileiensis) (Oxonii: Typographus academicus 1837).

L'art de bien vivre et de bien mourir (Paryż: Bocard 1453).

Livre de la Vigne nostre Seigneur (Bodleian Library MS. Douce 134) (facsimile), https://medieval.bodleian.ox.ac.uk/catalog/manuscript_451 [dostęp: 11.06.2021].

Mâle, É., L'art religieux de la fin du Moyen Âge en France. Étude sur l'iconographie du Moyen Age et sur ses sources d'inspiration (Paris: Colin 1908).

Opec, B., Żywot Pana Jezusa Chrystusa Stworzyciela i Zbawiciela [...]. Wedle edycji Jana Hallera z roku 1522 wydany przez Ks. Kan. Polkowskiego z Krakowa (Gniezno: Lange 1844).

Ovidius Naso, P., Metamorphoses (red. W.S. Anderson) (Lipsk:Teubner 1985).

Ovidius Naso, P., Tristia (red. J.B. Hall) (Lipsk: Teubner 1995).

Pesenti, G., „Lautore e la data del poema «Crisias»”, Atheneum. Studii Periodici di Letteratura e Storia (Pavia: Officina d'Arti Grafiche di Boriotti e Zolla 1922) X/1, 123-125.

Piccolomini, Aeneas Silvius, Carmina varia, http://mlat.uzh.ch/?c=15\&w=PicEne.Cava [dostęp: 11.06.2021].

Pitra, J.B. (red.), Spicilegium solesmense complectens sanctorum patrum scriptorumque ecclesiasticorum anecdota hactenus opera (Parisiis: Didot 1858).

Plutarch, De viris illustribus, tł. M. Brożek: Plutarch, Żywoty sławnych mężów (opr. T. Sinko) (Wrocław: Osolineum 1955).

Rhetorica ad Herennium. De ratione dicendi ad C. Herennium libri IV (red. F. Marx) (Lipsk: Tuebner 1923).

Romaniuk, K., „Apokryfy. II. Nowy Testament”, Encyklopedia katolicka (Lublin: TN KUL 1985) I, 762.

Rysiewicz, A., Zagadnienia retoryki w analizie poezji polskiej przełomu XVI i XVII wieku (Wrocław: Ossolineum 1990).

Sarbiewski, M.K., Dii gentium. Bogowie pogan (opr., tł. K. Stawecka) (Wrocław: Ossoineum 1972).

Sarbiewski, M.K., O poezji doskonałej czyli Wergiliusz i Homer [De perfecta poesi, sive Vergilius et Homerus] (tł. M. Plezia; opr. S. Skimina) (Wrocław: Ossolineum 1954).

Schmidt, P.G., „Die Crisias des Hilarion von Verona”, Ut Granum Sinapis. A Garland of Neo-Latin Studies in Honour of Jozef Ijsewijn (D. Sacré - G. Tournoy) (Supplementa Humanistica Lovaniensia 12) (Leuven: University Press 1997) 53-57.

Sedulius Caelius, Carmen Paschale, tł. pol. H. Wójtowicz: Sedulius Caelius, Opera omnia Dzieła wszystkie. Tekst łacińsko-polski (opr. H. Wójtowicz) (Lublin: Towarzystwo Naukowe KUL 1999) 86-221.

Signa quindecim horribilia de fine mundi et extremo iudicio (Köln: Martin von Werden 1505). 
Słowakowic, S., Postliminium cometarum abo raczej niebo z dawna a niesłusznie kometom przez filozofów odebrane, a teraz znowu [...] przywrócone (Kraków: Drukarnia Akademicka 1681).

Starowieyski, M. (red), Apokryfy Nowego Testamentu. I. Ewangelie apokryficzne. Opowiadania o Jezusie, Maryi, Józefie i Janie Chrzcicielu (Kraków: WAM 2003).

Starowieyski, M., Barwny świat apokryfów (Poznań: Drukarnia i Księgarnia św. Wojciecha 2015).

Statius Papinius, P., Thebais (Leipzig: Teubner 1908).

Strobl, W., Karl der Grosse im italienischen Renaissance-Humanismus. Die Vita Caroli Magni des Hilarion aus Verona für Francesco Tedeschini-Piccolomini (Wiener Studien - Beihefte 34; Wien: Vöaw 2012).

Valerius Maximus, Factorvm et dictorvm memorabilivm libri novem cum incerto fragmento de praenomonibus (red. C. Kempfius) (Berolini: Reimerus 1854).

Vergilius Maro, P., Aeneis / Eneis (red. O. Ribbeck) (Lipsiae: Teubner 1904).

Witkowska, A., „Miracula średniowieczne - funkcje przekazu ustnego i zapisu literackiego”, Kultura elitarna a kultura masowa w Polsce późnego średniowiecza (red. B. Geremek) (Wrocław et al.: Ossolineum 1978).

Włodek, Z., „Bessarion”, Encyklopedia katolicka (Lublin: TN KUL 1976) II, 329.

\section{Źródła internetowe}

http://www.mirabileweb.it/risultati.aspx?csel=6\&psel=2 https://data.cerl.org/thesaurus/ cnp02221649

http://www.bibliotecaitaliana.it/ 